\title{
ACHIEVING LIVES THROUGH THE SECRET OF PRAYER
}

\author{
Nurhadi \\ Kopertais XII Riau-Kepri \\ Jl. KH. Ahmad Dahlan 94, Indonesia \\ alhadijurnal@gmail.com
}

DOI: 10.46781/al-mutharahah.v18i1.159

\begin{abstract}
The Prayer Application Reaps Wisdom in fetching your dreams is Prayer Early Time. Prayers at the beginning of time show the level of faith, piety, and love for Allah. Congregational Prayers at the Mosque. Prayers in congregation are prayers performed by two or more people together. Prayers that are established in congregation reap benefits from the viewpoint of mathematics and economics, because they have multiple merit values, especially if they are performed in mosques that get 27 degrees. The Wisdom of Prayer Reaping Blessings is that Rawatib circumcision prayer is jewelry. The wisdom of the 24 cycles of rawatib prayer if it is carried out continuously or for eternity istiqomah it will become a jewelry for a person in the hereafter, it will become a jewelery on the face that carries out namely the emanation of faith and obedience Dhuha Prayer is Wealth is a sunnah prayer to seek and ask for sustenance. Tahajjud prayer is tranquility, because of the business of a believer, it sends a servant away and lulled by intimacy with Allah in the clear silence of the middle of the night, so that I get peace and serenity. Witir Prayer is Life because Witir Prayer is a right (life), so people who want to do it will get the right, every servant has the right to perform Witir prayer as much as he likes. One rak'ah, three, five, seven, nine and eleven. So if a servant exercises his right, namely witir prayer, then he has the right to get his right to life.
\end{abstract}

Keywords: future goals, the secret of prayer

\begin{abstract}
Abstrak
Aplikasi Sholat Menuai Hikmah dalam menjemput cita-cita adalah Sholat Awal Waktu. Shalat awal waktu menunjukkan tingkat keimanan, ketakwaan, dan kecintaan kepada Allah. Sholat Berjamaah di Masjid. Shalat berjama'ah adalah shalat yang dilakukan oleh dua orang atau lebih secara bersama sama. Sholat yang didirikan secara berjamaah menuai keuntungan dalam pandangan ilmu matematika dan ekonomi, karena mempunyai nilai pahala berlipat ganda, apalagi dilakukan di Masjid mendapat 27 derajat. Hikmah Sholat Menuai Berkah adalah Sholat sunat Rawatib adalah Perhiasan. Hikmah sholat rawatib 24 rakaat jika dilkasanakan kontiniu atau berkekalan istiqomah akan menjadi perhiasan seorang diakhirat, akan menjadi perhiasan diwajah yang melaksanakan yaitu pancaran keimanan dan ketaatan. Sholat Dhuha adalah Kekayaan merupakan shalat sunnah untuk mencari dan memohon agar dilapangkan rezeki. Sholat Tahajjud adalah Ketenangan, karena perniagaan orang yang beriman, menghantarkan seorang hamba hanyut dan terbuai kemesraan dengan Allah di hening bening tengah malam, sehingga hamba mendapatkan ketengan dan ketentraman. Sholat Witir adalah Kehidupan karena Sholat witir adalah hak (kehidupan), maka orang yang mau melaksanakanya akan mendapatkan hak, setiap hamba berhak melaksanakan sholat witir berapa dia sukai. Boleh satu rakaat, tiga, lima, tujuh, Sembilan dan sebelas. Maka jika seorang hamba melaksanakan haknya yaitu sholat witir, maka ia berhak mendapatkan hak hidupnya.
\end{abstract}

Kata Kunci: Cita-Cita, Rahasia Sholat. 


\section{A. Introduction}

The universe is Allah's creation, which consists of all matter, including energy and radiation as well as everything in space. The universe is immeasurable, its boundaries are unknown. Among them is the solar system of the Milky Way galaxy, in which the earth is the residence of mankind, this is explained by Allah in surah al-Baqarah verse $36 .{ }^{1}$ This verse explains that the earth is the residence for humans until the appointed time, namely the Day of Resurrection (for mankind) or death. The process of waiting for humans until the Day of Resurrection or until death comes, for humans to live their lives in this world (earth) has a duty as khilafah in accordance with the purpose of its creator, ${ }^{2}$ this can be seen in surah alAn'am verse $165 .^{3}$

The words of the caliph in the above verse contain global meanings, the scholars interpret with the support of other verses about the meaning of the caliph in the al-Qur'an, for example the Caliph for himself includes tasks: ${ }^{4}$ (1). Demanding knowledge (QS Al-Nahl: 43), because humans are creatures that can and must be educated / taught (QS al-Baqarah: 31) and who are able to educate / teach (Surah Al-Imran: 187 and al-An ' am: 51). (2). Guarding and maintaining oneself from everything that can cause danger and misery (Q.S al-Tahrim: 6) including maintaining and maintaining physical health, eating halal food and so on. (3). Adorn yourself with noble morals. The word morality comes from the word khuluq or khalq. Khuluq is a mental / spiritual form, and khalq is a physical form. ${ }^{5}$ Khalifah for family / household includes the duties: Forming a happy and prosperous household or a sakinah family, mawaddah and wa rahmah / loving kindness (QS ar-Rum: 21) by being aware of their rights and obligations as husband-wife or father-mother in household. As well as the caliph for the community includes the following tasks: (1). Realizing the unity and integrity of the ummah (Q.S al-Hujurat: 10 and 13 and al-Anfal: 46). (2). Please help in kindness and devotion (Surah al-Maidah: 2). (3). Upholding justice in society (Q.S al-Nisa: 135). (4). Responsible for mar ma'ruf nahi munkar ${ }^{6}$ (Surah Al-Imran: 104 and 110). (5). Applies well to weak groups of society, including the poor and orphans (QS al Taubah: 60 and al-Nisa ': 2), people with disabilities (QS' Abasa: 1-11), people who are under the control of others.

The goals and duties of the caliphate in themselves within the scope above, can be actualized by the servitude of themselves to the creator, ${ }^{7}$ as Allah says in surah al-Jariyat verse 56. ${ }^{8}$ Sayyid Qutub as quoted by Qurais Sihab commented on the above verse at length. He emphasized that the above verse, although very brief, contains a great and great essence. According to him, this verse opens up the many sides and various angles of meaning and purpose. The first side is that in essence there is a certain purpose for human beings and the jinn, it is a task. ${ }^{9}$ Whoever implements it has realized the purpose of his form, and whoever

\footnotetext{
${ }^{1}$ Departemen Agama RI, al-Qur'an dan Terjemahan (Semarang: Toha Putra, 2005), hlm. 14

${ }^{2}$ Menjadi khalifah. Lihat surah al-Baqarah ayat 30.

${ }^{3}$ Departemen Agama RI, al-Qur'an dan Terjemahan,..., hlm. 217

${ }^{4}$ Al-Raghib al-Isfahani, Mufradat Gharîb al-Qur'ân, (Mesir: Al-Halabi, 1961), hlm. 156-157. Lihat Ibn
} Manzur, Lisân al-'Arab, (Kairo: Dar al-Ma'arif, 1969), Juz X, hlm. 430. Lihat Fakhr al-Din al-Razi, al-Tafsir alKabîr, (Mesir: Al-Mathba'ah al-Mishriyyah, 1985), Jilid I, hlm. 180-181. Lihat Hasan Langgulung, Manusia dan Pendidikan, (Jakarta: Pustaka Al-Husna, 1989), hlm. 57. Lihat Musa Asy’arie, Manusia Pembentuk Kebudayaan dalam Al-Qur'an, (Yogyakarta: LSIF, 1992), hlm. 43.

5 Azyumardi Azra, Pendidikan Islam: Tradisi dan Modernisasi Menuju Milenium Baru, (Jakarta: Logos Wacana Ilmu, 1999), hlm. 8

${ }^{6}$ Muhammad Hasbi Ash Shiddieqy, Tafsir Al Qur'anul Madjied An Nur, (Jakarta: Bulan Bintang, 1973), hlm. 1

7 Anshori Umar Sitanggal, terj. Ahmad Mustafa Al-Maraghi, Tafsir Al-maragi juz XXV (Semarang: Thoha Putra, 1993), Cet. II, hlm. 24-25

${ }^{8}$ Departemen Agama RI, al-Qur'an dan Terjemahan, hlm. 862. Lihat Departemen Agama RI, AlQur'an dan Terjemah, (Jakarta: CV. J-ART, 2005), hlm. 523

${ }^{9}$ M. Quraish Shihab, Tafsir Al-Misbah, (Jakarta: Lentera Hati, 2002), vol. 13, hlm.112 
ignores it has canceled the essence of his form and becomes someone who has no duty, his life is empty with no purpose and ends in nothing. That task is worship of Allah, that is, selfservitude to Him. ${ }^{10}$ In the above verse the purpose of human creation is to serve and worship Allah SWT. The worship referred to in this verse is bowing and prostration as evidence of submission and obedience as well as gratitude or remembering the blessings of the creator as the all-wise and compassionate god of the universe, this can be seen in Surah Thoha verse $14 .^{11}$

It can be understood from the above verse that the purpose of prayer is to remember Allah SWT for all the favors that have been bestowed as a form of gratitude to him. Human gratitude to Allah basically benefits back to himself and this gratitude has the effect of adding blessings to his grateful servant. This is all stated in Allah's promise to his servant in his words of Surah al-Baqarah verse $152^{12}$ and surah Ibrahim verse $7 .{ }^{13}$

From the two verses above it can be understood that giving thanks to Allah swt returns to myself and will be added. These two verses are also supported by the hadith of the Prophet Muhammad in attaining a degree of gratitude with Allah SWT in Aisyah's narration: "Rasulullah SAW usually when he prays, he stands very long until his feet harden his skin. 'Aisha asked,' O Messenger of Allah, why did you get that way? Have not your sins been forgiven, past and future? Rasulullah besabda: 'O Aisyah, shouldn't I be a grateful servant?'. ${ }^{14}$ The above hadith means prayer as a form of gratitude for the servant to Allah Almighty, even though it is guaranteed to enter heaven and sins are forgiven, because very few people carry it out, even though the consequences of this worship are extraordinary in terms of the secret behind the wisdom of prayer.

Prayers occupy a high position in Islam. It is the second pillar and functions as a pillar of religion. Rasulullah said: "The leader of all matters (religion) is Islam (syahadatain), and the pillar is prayer". All the Shari'a of the apostles recommend and motivate their people to fulfill it, as Allah said to explain the prayer of Prophet Ibrohim as:" Yes my Rabb, make me and my children and grandchildren, those who continue to pray, $\mathrm{O}$ our Rabb, please allow prayer ' I ". [Ibrahim: 40]. ${ }^{15}$

From the above background, the formulation of the problem is how is the correct application in prayer and how is the urgency of prayer for life as well as human success physically and mentally?

\section{B. Research Method}

This study uses a librarian model using two sources, namely primary and secondary data. Primary data comes from the interpretation of al-Qurán and fiqhul shalah. Secondary data in the literature support this paper. The data analysis used content analysis method with a philosophical approach.

\section{Discussion}

1. Prayer applications that reap wisdom

a. Prayer at the Beginning of Time

Prayers at the beginning of time show the level of faith, piety, and love for Allah SWT. Love for Allah (mahabbatullah) will give birth to a longing to always want to meet. And the meeting with Allah mainly occurs in Salah so that it will never delay it. This is in

\footnotetext{
${ }^{10}$ Syaikh Imam Al Qurthubi, Tafsir Al Qurthubi, (Jakarta: Pustaka Azzam, 2009), hlm. 293-294

${ }^{11}$ Departemen Agama RI, al-Qur'an dan Terjemahan, hlm. 477

12 Departemen Agama RI, al-Qur'an dan Terjemahan, hlm. 38

${ }^{13}$ Ibid., hlm. 380

${ }^{14}$ HR. Bukhari No. 1130, Muslim No. 2820

${ }^{15}$ Departemen Agama RI, al-Qur'an dan Terjemahan, hlm. 386
} 
accordance with the word of Allah swt surah an-Nisa verse 103. ${ }^{16}$ The above verse is supported by the Prophet's hadith which states the virtue of praying at the beginning of the time: "ari 'Abdullah bin Mas'uud ra, he said: I once asked the Prophet about what deeds are most loved by Allah. He said: "Pray on time". Ibn Mas'uud said: "Then what?". He replied: "Do good to both parents". Ibn Mas'uud said: "Then what?". He replied: "Jihad in the way of Allah". ${ }^{17}$

Usman bin 'Affan ra said; "Whoever always performs the five prayers at the main time, Allah will glorify him with nine kinds of glory, namely: Beloved by Allah; His body is always healthy; His existence is always guarded by angels; His house is blessed; His face shows the identity of a pious person; His heart is softened by Allah.; He will cross the Shirath (bridge above hell) like lightning; He will be saved by God from the fires of hell; and Allah will place him in heaven. ${ }^{18}$

\section{b. Congregational Prayers at the Mosque}

Prayers in congregation are prayers performed by two or more people together and one of them is followed by another. ${ }^{19}$ Can be done anywhere without any restrictions, except where it is prohibited. Among the arguments for congregational prayer is in Surah an-Nissa verse $102^{20}$ and al-Baqarah verse $43^{21}$. Prayers that are established in congregation reap benefits from the perspective of mathematics and economics, because they have multiple reward values. This is in accordance with the hadith of the Holy Prophet: From Ibn Umar, that the Messenger of Allah said: (Praying in congregation is more important than praying alone twenty-seven degrees). (HR. Bukhari). ${ }^{22}$ It is prescribed for Muslims to pray in congregation because behind it there is a very great benefit and kindness. ${ }^{23}$

The most devoted congregational prayer is in the mosque, because the lightening of the footsteps leading to the mosque is a light of faith that is emitted in prayer activities. ${ }^{24}$ This is supported by Allah's revelation in surah at-Taubah verse $18 .^{25}$ The above verse is supported by many traditions about the importance of congregational prayer in the mosque. Among them are: A blind man came to the Holy Prophet and said, "O Messenger of Allah, I do not have anyone to guide me to the mosque," then he asked the Prophet for relief so that prayer at home was allowed. Then he saw to grant relief to him. When he left the Prophet, Rasulullah immediately called him and asked, "Did you hear the call to prayer to prayer?" He replied, "Yes." Then He said, "Fill it up!". ${ }^{26}$ After delivering his hujjah with this hadith, Ibn Qudamah said, "If a blind person who does not have anyone to accompany him, is not given relief, then

${ }^{16}$ Departemen Agama RI, al-Qur'an dan Terjemahan, hlm. 138

${ }^{17}$ HR. Bukhaariy No. $527 \& 5970 \& 7534$.

18 Satria Hadi Lubis, 6 Keutamaan Sholat Awal Waktu, http://www.ummi-online.com/keutamaanshalat-tepat-waktu-yang-perlu-diketahui.html,http://www.wajada.net/2017/03/6-keutamaan-sholat-

awalwaktu.html.diakses 14 oktober 2017

${ }^{19}$ Imam Ahmad Ibnu Hambal, Betulkah Shalat Anda, tarj. Umar Hubeis Bey Arifin, (Jakarta: Bulan Bintang, 1974), hlm. 125. Lihat Cyrl Glasse, Ensiklopedi Islam, tarj. Ghufron A. Mas'adi, (Jakarta: Raja Grafindo Persada, 1999), hlm. 487. Lihat Muhammad Baqir al-Habsyi, Fiqh Praktis, Menurut al-Qur'an, AsSunnah dan Pendapat Para Ulama, (Bandung: Mizan, 1999), hlm. 193

${ }^{20}$ Departemen Agama RI, al-Qur'an dan Terjemahan, hlm. 138

${ }^{21}$ Ibid., hlm. 16

22 Shalih bin Ghanim bin Abdillah As-Sadlani, Al-Jama'ah Hukmuha Wa Ahkamuha Wat Tanbih 'Ala Ma Yaqa'u Fiiha Min Bid'ain Wa Akhthain, edisi Indoensia Shalat Berjama'ah, Panduan Hukum, Adab, Hikmah (Pustaka Arafah), hlm. 61-65 2010), hlm.51-52

${ }^{23}$ Aisyah N Handryant, Masjid Sebagai Pusat Pengembangan Masyarakat, (Malang: UIN-Maliki Press,

${ }^{24}$ Eman Suherman, Manajemen Masjid Kiat Sukses Meningkatkan Kualitas SDM Melelui Optimalisasi Kegiatan Umat Berbasis Pendidikan Berkualitas Unggul, (Bandung: Alfabeta, 2012), hlm. 72-74

${ }^{25}$ Departemen Agama RI, al-Qur'an dan Terjemahan, hlm. 280

${ }^{26}$ HR. Muslim No. 1044. 
(who) is more". ${ }^{27}$ It is not that there are three people in one village or hinterland not enforced on them to pray, unless the Shaytan will rule it. Congregate you, because wolves only eat the goats that are alone. ${ }^{28}$ These nash-texts show how important prayer is in congregation. This opinion was shared by Lajnah Daimah Lil Buhuts wal Ifta '(The Standing Committee for Research and Fatwa of Saudi Arabia) ${ }^{29}$ and Shaykh Shalih bin Ghanim As Sadlan in his book Shalat Al Jama'ah. ${ }^{30}$

\section{Wisdom of Prayer that Reaps Blessings}

\section{a. Rawatib prayer is jewelry}

Among the functions of the Sunnah Prayer is to complete the Fardhu Prayer. The Prophet said: "The first practice that a servant will do on the Day of Resurrection is prayer (his). If the prayer is good, then really he will be successful and safe. And if it is lacking, then really he has been hurt and losers. If in the obligatory prayer there is something missing, then the Supreme Rabb, the Most Noble, says, "Look, whether my servant has the Sunnah Prayer. So the obligatory prayer is perfected with the Sunnah Prayer. Then (be) all the practice (obligatory) as (prayer practice) earlier." 31 Rawatib Sunnah Prayers are divided into 2 types: Muakkad Sunnah Prayers (highly emphasized). Based on the hadith from Umm Habibah, the wife of the Prophet, he said, I heard the Messenger of Allah say: "I have memorized from the Prophet sallallaahu 'alaihi wa sallam ten raka'at (sunnah rawatib), which is two rak'ahs before Zhuhur, two cycles after Zhuhur, two rak'ah after Maghrib, two rak'ah after 'Isha, and two rak'ah before Fajr". ${ }^{32}$

In addition to the 10 cycles above, the entire number of rawatib circumcision prayers is the ghairu muakkad circumcision. ${ }^{33}$ So all the rawatib circumcision prayers are 24 cycles, namely: 1). 2 cycles of dawn prayers and 2 cycles of qobliah at dawn. 2). 4 cycles of qobliah zuhur and 4 cycles of ba'diyah zuhur. 3). 4 cycles of qobliyah asyar. 4). 2 cycles of qobliyah maghrib and 2 cycles of ba'diyah maghrib. 5). 2 cycles of qobliyah isha and 2 cycles of ba'diyah isha. Whereas qobliyah jum'at and ba'diyah jum'at replace qobliyah zuhur and ba'diyah zuhur, the number of cycles is the same, which is 4 cycles before and after Friday.

The wisdom of the 24 cycles of rawatib prayer if it is done continuously or eternally istiqomah it will become a jewelry for a servant in the hereafter, it will become jewelry on the face of the person who carries out, namely the radiance of faith and obedience. Every time there is jewelry, people will glance at it and pay attention to it, even want to have it, therefore people who keep the rawatib circumcision prayer have their soul and face emanating from the world's jewelry, which is loved by people, jewelery in the hereafter, namely angels will always pray for it, and their deeds will be taken into consideration with other deeds in the hereafter.

\section{b. Dhuha Prayer is Wealth}

Dhuha prayers are performed when ascending ${ }^{34}$ and the rise of the sun reaches a height of 7 cubits Approximately $06.30^{35}$ This also depends on the time of dawn prayer and

${ }^{27}$ Al-Mughni, 3/6. Lihat majalah As-Sunnah Edisi 02/Tahun VII/1420H/1999M Diterbitkan Yayasan Lajnah Istiqomah Surakarta, Jl. Solo - Purwodadi Km. 8 Selokaton Gondangrejo Solo 57183 Telp. 08121533647,08157579296

${ }^{28}$ HR. Abu Dawud No.460, An Nasa'i No.738 dan Ahmad No. 26242.

${ }^{29}$ Fatawa Lajnah Daimah, juz 7, hlm. 283.

30 Ibid.

${ }^{31}$ HR. Abu Daud no. 864, dari Abu Hurairah. HR. Tirmidzi Juz 2, hlm. 413. Hadits ini dishahihkan oleh Syaikh Al-Albani dalam Ash-Shahihah Juz 3, hlm. 1358

${ }^{32}$ HR. Bukhari No. 1180.

33 As-Syaikh Abdullah bin Za'li Al-'Anziy, Tuntunan Shalat Sunnah Rawatib, Penerjemah: Abu Ahmad Meilana Dharma Putra (Buletin Darul Qosim (www.dar-alqassem.com), Muroja'ah: Al-Ustadz Abu Raihana, https://muslim.or.id/4602-tuntunan-shalat-sunnah-rawatib.html.diakses 15 oktober 2017.

34 Ubaid Ibnu Abdillah, Keutamaan dan Keistimewaan; Shalat Tahajud, Shalat Hajat, Shalat Istikharah, Shalat Dhuha, (Surabaya: Pustaka Media, t.th), hlm. 127. 
this is the beginning of the existence of living things on earth to carry out their respective activities until the time of midday prayer. ${ }^{36}$ In connection with this prayer Allah says in surah ad-Dhuha verse 1 and as-Syamsi verses 1-2. ${ }^{37}$ Namely the light, Abu Qatadha said wad Dhuhaha "in the morning" that is, the whole afternoon. ${ }^{38}$ Ibn Jarir said that the truth is to say: "Allah swears by the sun and its day, because the sun's rays are the most visible in the daytime." ${ }^{39}$ In the hadith it is explained that all the cells in the body ask for alms, then with the dhuha prayer everything will be paid off: "The Prophet said:" Let each of you give alms to every bone of your body every morning. Because every time the reading of the tasbih is sadaqah, every tahmid is alms, every tahlil is sadaqah, every takbir is sadaqah, telling the ma'ruf is alms, preventing what is wrong is sadaqah. And in exchange for all that, it is sufficient to do two rak'ahs of dhuha prayer". (Muslim 1181).

Duha prayer is basically the same as other circumcision prayers, namely two rak'ahs, but the number of rakats is practically unlimited, even though the benyak scholars limit it to 8 or 10 or even 12 cycles. ${ }^{40}$ The 4 rak'ah Dhuha prayer brings sufficiency for the whole day (a perfect and sufficient salary). ${ }^{41}$ Also hadith: "Allah 'Azza wa Jalla said," O son of Adam, do not escape the four rak'ahs at the beginning of your day, I will suffice for you throughout that day." (HR. Ahmad).

Dhuha prayer is the most ghanimah (wealth). ${ }^{42}$ One day the Prophet sallallaahu 'alaihi wasallam heard his companions talking about ghanimah (booty of war), so he showed more charity than ghanimah-ghanimah: "Whoever performs ablution then goes in the morning to the mosque to pray dhuha, then this is it is the closest war, the most ghanimah, and the return is faster "(Narrated by Tirmidhi and Ahmad). The explanation of this hadith indicates the virtue of Duha prayer and its relationship to sustenance. That whoever practices the duha prayer, he gets more from the spoils of war; both in terms of quantity of assets or blessings.

Dhuha prayer is a sunnah prayer with many advantages. People generally perform Dhuha prayers as a way to ask maghfirah (forgiveness from Allah), seek peace of life and ask for sustenance. ${ }^{43}$ Because in Duha prayer there is an explicit prayer in the form of a request to open the door of sustenance in the heavens and on earth. Sustenance is not always in the form of material or wealth. Useful knowledge, good deeds and everything that upholds one's religion are also referred to as sustenance. Types of sustenance provided by Allah for believers. Allah perfected their virtue and Allah granted them heaven on the last day. ${ }^{44}$ The prayer dhuhanya prayer is: O my Lord, actually dhuha time is Your dhuha time, majesty is Your majesty, beauty is Your beauty, strength is Your strength, guard is Your guard, O my Lord, when my sustenance is above the sky then bring it down, when it is in the earth then bring it out, if it is difficult to make it easy, if it is haram purify it, if it is far closer to the truth of Your dhuha, Your power (O my Lord), bring me what You bring to Your pious servants. From the hadiths and prayers above, it can be understood that Duha prayer teaches people to be rich and only begs and asks only from Allah through Duha prayer. So the prayer of dhuha

35 M. Imron, Penuntut Sholat Dhuha (Surabya: Karya ilmu, 2006), hlm. 3. Lihat Depdikbud, Kamus Besar Bahasa Indonesia, Edisi Kedua, (Jakarta: Balai Pustaka, 1994).hlm. 79.

${ }^{36}$ Sayyid Sabiq, Fikih Sunnah, Terj. Khairul dkk. (Jakarta: Cakrawala Publising, 2008), hlm. 362. Lihat Syaikh Hasan Ayyub, Fikih Ibadah, terj,. Abdul Rasyid Shiddiq, (Jakarta: pustaka Al-Kautsar, 2002), hlm. 442

${ }^{37}$ Ibid., hlm. 1064

${ }^{38}$ Syaikh Muhammad bin Shalih Al-Ustaimin, Tafsir jus Amma'.terj. Abu Ihsan Al-Atsari, (Solo: AtTibyan), hlm. 40

${ }^{39}$ Abdullah bin Muhammad bin “Abdurrahman bin Ishaq Alu Syaikh, Tafsir Ibn Katsir, terj,. M. Abdul

Ghaffar, Abu Ihsan Al-Atsari, (Jakarta: Pustaka Imam Asy-syafi" i, 2007), hlm. 480

${ }^{40}$ Moh Rifa'I, Kumpulan Sholat-Sholat Sunnah (Semarang: Cv toha putra, 1993), hlm. 49

${ }^{41}$ Erwin-Y, Hikmah Sholat Dhuha (Publis: 05-10-2011 13:23:34), hlm. 1

${ }^{42}$ Ibid.

${ }^{43}$ Ubaid Ibnu Abdillah, Keutamaan dan Keistimewaan, hlm. 127

${ }^{44}$ Ibid. 
is wealth, a servant who wants to be rich in wealth and heart, it is recommended to recite the dhuha prayer every day according to the Prophet's teachings, then God willing will be rich.

\section{c. Tahajjud Prayer is Serenity}

Tahajud comes from the language of the word "tahajjada" which means to wake up with a body weight, so the condition for carrying out midnight prayers according to the majority of scholars is to sleep first. In terms of tahajud, it is the sunnah prayer that is done at night after completing the evening prayer and after waking up. ${ }^{45}$

Midnight prayer is the sunnah prayer that is performed at night after completing the evening prayer until dawn and after waking up, even if only for a short time. The law of tahajud prayer is the sunnah mu'akkad, which is a sunnah that is highly recommended to be practiced. Therefore, the prophet strongly encouraged his people to always carry out midnight prayers. ${ }^{46}$

In connection with the tahajjud Allah Almighty said in surah al-Isra verse $79 .{ }^{47}$ And the Holy Prophet accepted and carried out this noble rabbani instruction. Aisyah ra said: When the Messenger of Allah prayed at night then he would wake up so that his legs were swollen, Ayesha said: Are you doing this when Allah has forgiven your past and future sins. So the Messenger of Allah replied: O Ayesha, is it not more for me to be a grateful servant. ${ }^{48}$ This history is also supported by the word of Allah in Surah as-Sjadah verses $16-17 .{ }^{49}$ In fact, between the most devoted worship after fardhu prayer and the most noble obedience recommended by the Shari'a is qiamullail, it is the custom of the pious people, the commerce of believers, at night those who believe preach with their Rabb report their plight to Him, and they ask of His mercy. Serenity with Allah at midnight prayers is clearly seen in the prayer taught by the Prophet: "Yes, Allah! Praise be to You, You are the light of the heavens and the earth and everything in them. Praise be to You, You take care of heaven and earth and everything in it. Praise be to You, You are the Lord who rules the heavens and the earth and everything in it. Praise be to you and to the kingdom of heaven and earth and all that is in it. Praise to You, You are true, Your promises are true, Your words are true, meeting You is true, Heaven is true (there is), Hell is true (exists), (the sending of) the prophets is true, (the sending off) Muhammad is true (of You), the events of the Last Day are true. O Allah, I surrender to You, I put my trust in You, I believe in You, I return to You (repent), with Your help I argue (to unbelievers), to You (and with thy teaching) I impose the law. Therefore, forgive my past and future sins. It is you who prioritize and end, no God has the right to be worshiped except You, You are my God, there is no God who has the right to be worshiped except You ". From the tahajjud prayer above, it can be understood that the prayer sends a servant away and lulled by intimacy with Allah in the clear silence of the middle of the night, so that I get peace and serenity, ${ }^{50}$ It is evident that the Prophet did this until the heels and knees were swollen but did not hurt, ${ }^{51}$ even midnight prayers can be a therapy for heart and soul diseases, which have implications for healing physical ailments.

\section{d. Witir Prayer is Life}

The witir circumcision prayer is part of the night circumcision prayer, which is usually accompanied by the tahajjud prayer. Witir prayer is an odd prayer one of the closing night

\footnotetext{
${ }^{45}$ Sobron Zayyan, Dahsyatnya Shalat Fardhu dan Sunnah (Bandung: Kawan Pustaka, 2011), hlm. 123

${ }^{46}$ Muhammad Muhlisin, Amalkan Shalat Tahajud \& Dhuha Pasti Hidupmu Sukses, Kaya \& Bahagia (Yogyakarta: Lafal, 2014), hlm. 35.

${ }^{47}$ Departemen Agama RI, al-Qur'an dan Terjemahan, hlm. 436

${ }^{48}$ Shahihl Bukhari: 1/352 no: 1130

${ }^{49}$ Departemen Agama RI, al-Qur'an dan Terjemahan, hlm. 662

${ }^{50}$ HR.Bukhari \& Muslim. Lihat Said bin Ali bin Wahf al-Qathani, Ensiklopedi shalat, (Jakarta: Pustaka imam Syafi'e, 2006), hlm. 425

${ }^{51}$ HR. Bukhari No. 1130, Muslim No. 2820. Lihat Said bin Ali bin Wahf al-Qathani, Ensiklopedi shalat, (Jakarta: Pustaka imam Syafi'e, 2006), hlm. 418
} 
prayers and tahajjud circumcision prayers. As Rasul SAW said: "Make the end of your prayers at night with Witir prayers." 52 Witir prayer is an odd prayer done at night, in the hadith of 'Ali bin Abi Talib ra, he said, that the Messenger of Allah said: "Verily Allah is odd and likes people who perform Witir prayers, then Witir prayer, O experts. Al-Qur'an." ${ }^{, 53}$ Ibn 'Umar Radhiyallahu anhuma said, "Whoever prays the sunnah at night, let him make the end of his prayer Witir prayer, because the Messenger of Allah ordered it. ${ }^{54}$ From Abu Ayyub alAnsari Radhiyallahu anhu, he said that the Messenger of Allah said: "Witir prayer is haq (it is true), so whoever wants, then whoever wants, has three cycles and whoever wants to do it. those who want, have one raka'at. Witir prayer is a right (life), so people who want to carry it out will get the right, every servant has the right to perform witir prayers as much as he likes. One rak'ah, three, five, seven, nine and eleven. So if a servant exercises his right, namely witir prayer, then he is entitled to his right to life. So that the Prophet said close your night with witir, in the hope that waking up will get the goodness and rights of his life. So the witir prayer is called the prayer of life. This can also be analyzed from the witir prayer: O Allah. Indeed, we ask You for constant faith, we ask You for a special heart ', we ask You for useful knowledge, we ask You for true belief, we ask You for righteous deeds, we ask -You are a righteous religion, we ask You for a lot of goodness, we ask You for forgiveness and afiat, we ask You for perfect health, we ask You for health, and we ask You for the richest of all human. O Allah, our Lord. Please accept from us our prayers, our fasts, our night prayers, our specialties, our humility, our worship. Make up for our negligence or shortcomings, O Allah, O Allah, O Allah, O Allah, the Most Merciful among the Merciful. May Allah's grace be poured out to the best of His creatures, Muhammad, his family and friends, and all praise belongs to Allah, Lord of the universe. From the prayer above, it is very clear that witir prayer is the light of life and the radiance of life. So everyone who chants witir prayers will be gifted with a long life or a long life. Because the prayer above asks for all the rights needed in life as a servant, as well as the surrender of life only for and belonging to Allah swt.

\section{Conclusion}

Prayer applications that reap wisdom are as follows:

1) Prayer at the Beginning of Time. Prayers at the beginning of time show the level of faith, piety, and love for Allah SWT.

2) Prayers in congregation at the mosque. Prayers in congregation are prayers performed by two or more people together and one of them is followed by another. Prayers that are established in congregation reap benefits from the viewpoint of mathematics and economics, because they have multiple reward values, especially if done in a mosque that gets 27 degrees.

The wisdom of prayer that reaps blessings is as follows:

1) Rawatib prayer is jewelry. The wisdom of the 24 cycles of rawatib prayer if it is done continuously or eternally istiqomah it will become a jewelry for a servant in the hereafter, it will become jewelry on the face of the person who carries out, namely the radiance of faith and obedience. Every time there is jewelry people will glance at it and pay attention to it, even want to have it, therefore people who keep the rawatib circumcision prayer have their souls and faces emanating from the world's jewelry, which is loved by people, jewelery in the hereafter, namely angels will always pray for it, and their deeds will be taken into consideration with other deeds in the hereafter .

2) Dhuha Prayer is Wealth. Dhuha prayer is a sunnah prayer with many features. People generally perform Dhuha prayers as a way to ask for maghfirah (forgiveness from

\footnotetext{
${ }^{52}$ HR. Al-Bukhari No. 998) dan Muslim No. 751

${ }^{53}$ HR. Abu Dawud No. 1416

${ }^{54}$ HR. Muslim No. 751
} 
Allah SWT), seek peace of life and ask for sustenance. Dhuha prayer teaches people to be rich and only ask and ask only from Allah through Duha prayer. So the dhuha prayer is wealth, a servant who wants to be rich in wealth and heart, it is recommended to recite the dhuha prayer every day according to the Prophet's teachings, then God willing, he will be rich.

3) Tahajjud Prayer is Serenity. Indeed, among the most devoted acts of worship after fardhu prayer and the most noble obedience recommended by syara 'is qiamullail, he is the habit of the pious people, the business of those who believe, at night the believers preach with their Rabb, reported their situation to Him, and they asked from His grace. Tahajjud prayer delivers a servant drifting away and lulled by intimacy with Allah in the clear silence of the middle of the night, so that I get peace and tranquility, it is proven that the Prophet did it until the heels and knees were swollen but did not feel pain, even the midnight prayer could become a disease of the heart and soul, which has implications for healing physical ailments.

4) Witir Prayer is Life. Witir prayer is a right (life), so people who want to carry it out will get the right, every servant has the right to perform witir prayers as much as he likes. One rak'ah, three, five, seven, nine and eleven. So if a servant exercises his right, namely witir prayer, then he is entitled to his right to life. So that the Prophet said close your night with witir, in the hope that waking up will get the goodness and rights of his life. So the witir prayer is called the prayer of life.

\section{BIBLIOGRAPHY}

Abdullah bin Muhammad bin "Abdurrahman bin Ishaq Alu Syaikh, Tafsir Ibn Katsir, terj,. M. Abdul Ghaffar, Abu Ihsan Al-Atsari, (Jakarta : Pustaka Imam Asy-syafi'i, 2007.

Abu Ubaidah Syafrudin, Hikmah Di Balik Shalat Berjamaah, http://asysyariah.com/hikmahdi-balik-shalat-berjamaah/.Jun 2, 2013 | Asy Syariah Edisi 087, Kajian Utama.diakses 15 oktober 2017

Abu Ubaidah Yusuf bin Mukhtar as-Sidaw, sholat berjamaah (Publication: 1434 H-2013 M)

Aisyah N Handryant, Masjid Sebagai Pusat Pengembangan Masyarakat. Malang: UINMaliki Press, 2010.

Al-Raghib al-Isfahani, Mufradat Gharîb al-Qur'ân. Mesir: Al-Halabi, 1961.

Ibn Manzur, Lisân al-'Arab. Kairo: Dar al-Ma'arif, 1969. Juz X

Amin Abdullah Asy-Syaqawy, Keutamaan Sholat Malam. Islamhouse.com, 2009-1430 H.

Anshori Umar Sitanggal, terj. Ahmad Mustafa Al-Maraghi, Tafsir Al-maragi juz XXV. Semarang: Thoha Putra, 1993. Cet. II

As-Syaikh Abdullah bin Za'li Al-'Anziy, Tuntunan Shalat Sunnah Rawatib, Penerjemah: Abu Ahmad Meilana Dharma Putra (Buletin Darul Qosim (www.dar-alqassem.com), Muroja'ah: Al-Ustadz Abu Raihana, https://muslim.or.id/4602-tuntunan-shalatsunnah-rawatib.html.diakses 15 oktober 2017.

Azyumardi Azra, Pendidikan Islam: Tradisi dan Modernisasi Menuju Milenium Baru. Jakarta: Logos Wacana Ilmu, 1999.

Cyrl Glasse, Ensiklopedi Islam, tarj. Ghufron A. Mas'adi. Jakarta: Raja Grafindı srsada, 1999.

Departemen Agama RI, Al-Qur'an dan Terjemah. Jakarta: CV. J-ART, 2005.

Departemen Agama RI, al-Qur'an dan Terjemahan. Semarang: Toha Putra, 2005.

Depdikbud, Kamus Besar Bahasa Indonesia, Edisi Kedua. Jakarta: Balai Pustaka.

Eman Suherman, Manajemen Masjid Kiat Sukses Meningkatkan Kualitas SDM Melelui Optimalisasi Kegiatan Umat Berbasis Pendidikan Berkualitas Unggul. Bandung: Alfabeta, 2012.

Erwin-Y, Hikmah Sholat Dhuha. Publish: 05-10-2011 13:23:34. 
Fakhr al-Din al-Razi, al-Tafsir al-Kabîr. Mesir: Al-Mathba'ah al-Mishriyyah, 1985. Jilid I Hasan Langgulung, Manusia dan Pendidikan. Jakarta: Pustaka Al-Husna, 1989.

Imam Ahmad Ibnu Hambal, Betulkah Shalat Anda, tarj. Umar Hubeis Bey Arifin. Jakarta: Bulan Bintang, 1974.

M. Imron, Penuntut Sholat Dhuha. Surabya: Karya ilmu, 2006.

M. Quraish Shihab, Tafsir Al-Misbah. Jakarta: Lentera Hati, 2002. vol. 13

Majalah As-Sunnah Edisi 02 / Tahun VII / 1420H / 1999M Diterbitkan oleh Yayasan Lajnah Istiqomah Surakarta, J1. Solo-Purwodadi Km. 8 Selokaton Gondangrejo Solo 57183 Tel. $08121533647,08157579296$.

Moh Rifa'I, Kumpulan Sholat-Sholat Sunnah. Semarang: CV Toha Putra, 1993.

Muhammad Baqir al-Habsyi, Fiqh Praktis, Menurut al-Qur'an, As-Sunnah dan Pendapat Para Ulama. Bandung: Mizan, 1999.

Muhammad bin Salih Al-Uthaimin, Asy-Syarh Al-Mumti 'Ala Zaad Al-Mustaqni. t.tp: Darus Sunnah, t.t), Bab 2

Muhammad Hasbi Ash Shiddieqy, Tafsir Al Qur'anul Madjied An Nur. Jakarta: Bulan Bintang, 1973.

Muhammad Muhlisin, Mengamalkan Solat Tahajud \& Dhuha Akan Menjadikan Hidup Anda Berjaya, Kaya \& Bahagia. Yogyakarta: Sebutan, 2014.

Musa Asy'arie, Manusia Pembentuk Kebudayaan dalam Al-Qur'an, (Yogyakarta: LSIF, 1992.

Qurais Sihab, Tafsir al-Misbah dan tafsir Jalalin online https://tafsirq.com/2-al-baqarah/ayat36\#tafsir-jalalayn.diakses 14 oktober 2017.

Berkata bin Ali bin Wahf al-Qathani, Ensiklopedia sholat. Jakarta, Pustaka Imam Syafi'e, 2006.

Salim. Bahreisj, Tarjamah Riadhus Shalihin II. Bandung: Alma'arif Bandung, 2001.

Satria Hadi Lubis, 6 Keutamaan Sholat Awal Waktu, http://www.ummionline.com/keutamaan-shalat-tepat-waktu-yang-perlu-

diketahui.html,http://www.wajada.net/2017/03/6-keutamaan-sholatawalwaktu.html.diakses 14 oktober 2017

Sayyid Sabiq, Fiqh Sunnah, trans. Khairul et al. Jakarta: Cakrawala Publising, 2008.

Shalih bin Fauzan al-Fauzan, Tashil al-Ilmam bi Fiqhi al-Ahadits Min Bulugh al-Maram. t.t: t.p, $1427 \mathrm{H}$, cet. I, juz 2

Shalih bin Ghanim bin Abdillah As-Sadlani, Al-Jama'ah Hukmuha Wa Ahkamuha Wat Tanbih 'Ala Ma Yaqa'u Fiiha Min Bid'ain Wa Akhthain, edisi Indoensia Shalat Berjama'ah, Panduan Hukum, Adab, Hikmah: Pustaka Arafah.

Sobron Zayyan, Kekuatan Solat Fardhu dan Sunnah. Bandung: Kawan Pustaka, 2011.

Shaykh Hasan Ayyub, Ibadah Fiqh, trans. Abdul Rasyid Shiddiq, Jakarta: pustaka Al-Kautsar, 2002.

Syeikh Imam Al Qurthubi, Tafsir Al Qurthubi, Jakarta: Pustaka Azzam, 2009.

Shaykh Muhammad bin Salih Al-Ustaimin, Tafsir jus Amma'.terj. Abu Ihsan Al-Atsari. Solo: At-Tibyan.

Ubaid Ibn Abdillah, Keutamaan dan Keistimewaan; Solat Tahajud, Solat Hajat, Solat Istikharah, Solat Dhuha.Surabaya: Pustaka Media, t.th. 